\title{
Editorial
}

\section{Dentitio difficilis or Teething- scapegoat for quandaries in infants}

\author{
Vipin Ahuja ${ }^{1, *}$, Annapurna Ahuja ${ }^{2}$ \\ ${ }^{1}$ Dept. of Pediatric and Preventive Dentistry, Hazaribag College of Dental Sciences and Hospital, Hazaribag, Jharkhand, India \\ ${ }^{2}$ Dept. of Periodontics and Implant Dentistry, Hazaribag College of Dental Sciences and Hospital, Hazaribagh, Jharkhand, \\ India
}

\section{A R T I C L E I N F O}

Article history:

Received 05-01-2022

Accepted 20-01-2022

Available online 31-01-2022

\begin{abstract}
This is an Open Access (OA) journal, and articles are distributed under the terms of the Creative Commons Attribution-NonCommercial-ShareAlike 4.0 License, which allows others to remix, tweak, and build upon the work non-commercially, as long as appropriate credit is given and the new creations are licensed under the identical terms.
\end{abstract}

For reprints contact: reprint@ipinnovative.com
Dentitio difficilis or difficult dentition are the synonyms used for "Teething." 1 According to a Manual of Paedodontics by R.J. Andlaw and W.P. Rock, Teething is defined as a process by which the teeth erupt after penetration of the overlying gums. ${ }^{2}$ The word, 'teething' is derived from a French word, 'teethe' which means 'cuts one teeth' ${ }^{3}$ Tooth eruption takes place during an 8-day window that includes 4 days before tooth eruption, the day of eruption and the 3 subsequent days. ${ }^{4}$

\section{Is teething pathological or physiological?}

There are 3 schools of thought for teething: 5

1. First school, some clinicians (James, 1954) believe teething produces a great difficulty - systemic and local in nature

2. Second school, some (Colyer and Sprawson, 1942; Illingworth, 1953) consider that mild disturbances and expected consequences are common.

3. Finally the third school, there are those people (Feer,1928 and Janssen, 1955) who claim that eruption is a normal process, disease or disturbances cannot occur.

And the most considered notion is that "Teething will produce teeth and nothing else"

\footnotetext{
* Corresponding author.

E-mail address: drvipinahuja@gmail.com (V. Ahuja).
}

Local and systemic signs of teething 5,6

Table 1:

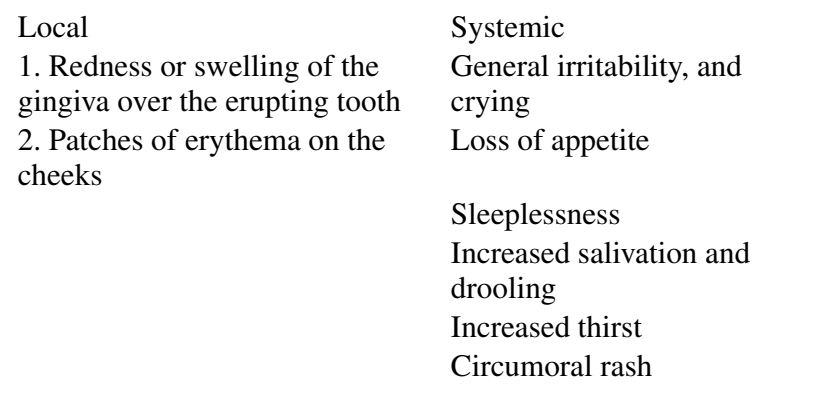

\section{Possible explanations for signs of teething}

Explanations given by Margaret H. Seward ${ }^{5,6}$

1. General irritability: is the most common disturbance to occur during the eruption of primary teeth. According to the author, anxiety and behavior disorders in infants and young children have been attributed inappropriately to teething.

2. Restless and unable to sleep: is the second most common disturbance to occur during the eruption of the anterior teeth. As per Illingworth, much of evening and nocturnal crying of 6-12 months old babies 
ascribed to teething is due to bad habit formation and mismanagement.

3. Drooling: refers to the escape of saliva from oral cavity in the form of bubbles or as a continuous trickle. Drooling occurs more commonly during eruption of the anterior teeth than of the posterior teeth. It is probably caused by the excessive salivation that accompanies newly matured salivary glands coupled with the failure on the part of the infant to swallow the increased salivary flow. Also, excessive salivation may be the direct result of the pain and discomfort experienced by a child when teething occurs. It may be that the infant is unable to swallow the saliva because of a change in the quality; for example, the saliva may exhibit an increased viscosity during this period.

4. Loss of appetite : there is a lot of speculation regarding weight loss of the child during this time span. It was also found that mother's judgment was accepted as sufficient in determining whether the infant ate less food during the period of tooth eruption, which is scientifically inappropriate. It has also been documented that during this teething period the weight of the infant remains stationary or decreases slowly.

5. Circumoral rash: occurred more commonly with the eruption of the posterior teeth than anterior teeth. The explanation provided is that saliva which escapes from oral cavity is frequently retained in the facial folds and the resultant moist conditions encourage the appearance of a rash.

Many authors feel that eruption of deciduous teeth is a physiologic process and fever and systemic disturbances are related to infections, loss of maternal antibodies, and development of immunological responses during this period of child growth and development. ${ }^{7}$ L.Jaber, I J Cohen, A Mor $^{8}$ studied the association of fever with teething in a study and inferred that no definite evidence was established to support the relationship of teething with other systemic disturbances except low grade fever. Honig ${ }^{9}$ states that modern pediatrics and dentistry can no longer accept teething as a cause of fever and diarrhea.

\section{Conflict of Interest}

The authors have stated explicitly that there are no conflicts of interest in connection with this article.

\section{Source of Funding}

None.

\section{References}

1. Teething difficulties- dentitio difficilis [Internet]; [updated 2020; cited 2021 December 15. Available from: https://second.wiki/wiki/dentitio_ difficilis.

2. Andlaw RJ, Rock WP. A manual of paedodontics. 2nd Edn. Churchill Livingstone dental series. New York : Churchill Livingstone: Edinburgh ;; 1987.

3. Webster's Third New International Dictionary Hardcover - Unabridged, 10 September 2008

4. Markman L. Teething: facts and fiction. Pediatr Rev. 2009;30(8):5964. doi:10.1542/pir.30-8-e59.

5. Seward MH. Local disturbances attributed to eruption of the human primary dentition. A survey. Br Dent J. 1971;130(2):72-7. do1:10.1038/s].bdj.4802630.

6. Seward MH. General disturbances attributed to eruption of the human primary dentition. ASDC J Dent Child. 1972;39(3):178-83.

7. Mcintyre G, Mcintyre G. Teething troubles? $\mathrm{Br}$ Dent J. 2002;192(5):251-5. doi:10.1038/sj.bdj.4801349.

8. Jaber L, Cohen. IJ Mor A Fever associated with teething. Arch Dis Child. 1992;67:233-4.

9. Honig PJ. Teething-Are today's pediatricians using yesterday's

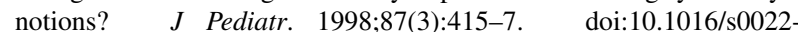
3476(75)80645-7.

\section{Author biography}

Vipin Ahuja, Professor and Head

Annapurna Ahuja, Professor \& Head

Cite this article: Ahuja V, Ahuja A. Dentitio difficilis or Teething-

scapegoat for quandaries in infants. J Dent Panacea 2021;3(4):147-148. 